\title{
Trk Family Neurotrophin Receptors and p75 Receptor. A Multiple Competing Hypothesis Case in the Nerve Growth Factor (NGF) History
}

\author{
Enrique Wulff Barreiro \\ Marine Sciences Institute of Andalusia, Spanish National Research Council (CSIC), Puerto Real (Cádiz), Spain \\ Email: enrique.wulff@icman.csic.es
}

Received 10 October 2013; revised 8 December 2013; accepted 21 December 2013

Copyright (C) 2014 by author and Scientific Research Publishing Inc.

This work is licensed under the Creative Commons Attribution International License (CC BY). http://creativecommons.org/licenses/by/4.0/

(c) (1) Open Access

\begin{abstract}
In the area of Trk oncogene, this research has revealed the different competing hypotheses made at the time of its discovery. A conflict of interest arose within the group who identified it as the nerve growth factor receptor (NGF). An auxiliary assumption, on the cardinal importance of the low affinity p75 receptor, resulted in that the consistency of the group take patterns of competence. The level of provocation affected the joint effort. An environment reminds the denial that Stehelin was given by Varmus and Bishop, in the race for the Nobel Prize in Physiology or Medicine. Nowadays p75 receptor functions are described as "enigmatic", and accepted that all the neurotrophins interact with two types of receptors: the specific to the ligands of the high-affinity Trk family of receptors and the low affinity p75 receptor (with structural similarities to the tumor necrosis factor and in liaison with the development of eye optical fiber). Against this background, papers concerning this subject and included in the ISI citation database are analysed, categorizing them through a system of descriptors, according to their original publication date. Complete time vectors are approximated by setting the analysis with a growth model based on Gompertz function. After the criteria used by authorities like Rita Levi-Montalcini, Luigi Cavalli-Sforza, Rodolfo Llinás and Victor McKunsick the selected material resulted in a database with 371 records. The data suggest the opportunity for historical sciences of a non-discrimination compliance test performed on multiple hypotheses.
\end{abstract}

\section{Keywords}

Oncogenetics; NGF; Neurotrophin; Trk; p75; History of Neurosciences 


\section{Introduction}

Early in the nineties of 20th century it was known that nerve growth factor (NGF), a molecular Rosetta stone, has a receptor with oncogenic nature. In the February 1986 issue of Nature, Mariano Barbacid and his team discovered the tyrosine kinase gene, which plays a fundamental role in the maintenance of neurological functions. The same year Rita Levi-Montalcini received a Nobel prize for NGF. NGF is a chemical body which stimulates the proliferation of neuronal extensions (the dendrite or axon) and makes their way to those cells with which the nerve cell is to establish contact. By analyzing tyrosine kinases and their enzymes, scientists hoped to chart the signaling pathways of several oncogenic proteins. And Barbacid definitive proof that Trk gene was a proto-oncogene marked a new development in the fight against cancer. In fact, a transmembrane tyrosine kinase, this proto-oncogene termed Trk (tropomyosin related kinase), was identified in 1991 by Mariano Barbacid as the nerve growth factor receptor (Pellicer, 2004).

Mariano Barbacid, a Madrid-born scientist, was the first who cloned a human oncogene in 1981. Together with two Spanish biologists (Eugenio Santos and Vicente Notario), the Italian Simonetta Pulciani and the north American biologists Linda Long and Anne Lauver they discovered the mutated gene H-ras implied in bladder cancer. This work combined gene engineering techniques with transfection techniques (inoculation into the cell of the cancer gene), that Barbacid learnt from the Catalan pathologist Ángel Pellicer.

It was at one time possible for scientists to share freely biological materials, and genetic data. Today, when genetic sequences, microorganisms and research animals, computer algorithms, university conferences, and even surgical techniques fall within the scope of the intellectual property domain, this is no longer the case. Generally speaking these are all frontier objects, scheme that favors a diversity of priority claims and which conflicts with its social and legal status (Krimsky, 2002). We understand that a conflict of interests has occurred inside the group which identified the human Trk proto-oncogene. And a frontier domain was defined as soon as appeared the auxiliary assumption on the role of the low affinity p75 receptor.

This protein tyrosine kinase family is the neurotrophin receptors set. The discovery that in cells expressing Trk receptors, neurotrophins promote cell survival changed everything previously knew about NGF. Indeed, by 1990, NGF had been known about for almost 40 years and it was thought that all have already been said about it.

Neurotrophins (NGF, brain-derived neurotrophic factor (BDNF), neurotrophin-3 and neurotrophin-4) are factors enhancing nerve cells growth potentialities. Nerve growth factor was the first growth factor identified, historically discovered by Rita Levi-Montalcini, in a work that began in 1949 following the suggestion of Victor Hamburger. The regulation of growth factors in neuronal development has rendered the difference between growth factors and neurotrophic factors useless, taking into account that neurotrophins show numerous effects on non neuronal cells (specially on cells of the immune system). Due to the large number of actions attributed to these molecules, a current definition of neurotrophins covers the maturation, regeneration, differentiation, and even neuronal death among other issues.

Neuronal growth factor receptors temporally regulate cellular sensitivity to growth factors in their environment. Receptors are transmembranal because the answer of a cell to a particular growth factor depends on the expression of specific receptors in cell membranes (Siegel, 1998). Neurotrophins information transmission through its receptors toward the interior of the cell is translated into their adscribed effects (Vecino, 1998). So a "new avenue to research for neurobiologists" was opened in 1991 with the discovery by a Spaniard of the nerve growth factor (NGF) Trk receptor.

\section{Objective}

The objective pursued is to detect the differences between the scientific careers of the biologists Parada and Martín Zanca and the chemists Barbacid, with regard to Trk oncogene. To accomplish this, we employ a MannWhitney test by computing the $\mathrm{U}$ statistic, calculating an acceptance region for null hypothesis and by examining the validity of such an hypothesis (Conover, 1980) (Egghe \& Rousseau, 1990). The null hypothesis will be rejected if the scientific content of the programs differ.

Parada had play a role in the oncogene race, identifying Barbacid's work on T24 bladder gene, with Earl Jensen bladder gene results from the lab where he worked in 1980.This was an episode that a non-parametric proof can pose by testing two rival hypotheses; it is adequate when a priori information is not available on the distribution of population in the authors whose normative expectations and behavioral patterns evolve adjusted to two scientific practices against each other. 
A clear indication of subject category, its frequency, shows the more or less use of key words in the records analyzed in the SCI (ISI Thompson) database that are retrieved to answer the research questions. Referring Figure 1, in the year 1985 a postdoc then working with Mariano Barbacid at the National Cancer Institute, Frederick, Maryland, (Dionisio Martín Zanca) was involved in the cloning of a gene, called the Trk gene, from colon cancer cells [Art. 3, Appendix 1]. In 1987 and 1990, Luis Parada and David Kaplan come to Frederick [Art. 9]. Barbara Hempstead and Moses Chao, from Cornell University Medical College, collaborate to build the group Chao \& Parada (April 26, 1991, "p75K protein is clearly implicated in nerve growth factor (NGF) actions" [Art. 13]). Barbacid had published, three weeks before, an almost identical result, although he did not involve the low affinity receptor [Art. 8].

Table 1 shows significant differences. The largest sub collections of published documents on Trk, retrieved from SCI (ISI Thompson) database are those of the authors Parada (41 papers) and Barbacid (35). Differences in leadership between these two scientists are relevant to an ordinal scale of subject categories. On the other hand, Martín-Zanca is much closer to Barbacid than to Parada.

The chosen time interval is 1986-2005. However, Medline indicators did not use the term "Neurotrophin" until 1990 (as suggested by the question "Neurotrophin" [mh] not 1991:2005 [dp]"); nor that of "nerve growth factor receptor" until 1980, as indicated by the query "Receptors, Nerve Growth Factor [mh] not 1981:2005 [dp]"); neither 'Trk receptor" until 1988 (as expressed by the search "Receptor, Trk" [mh] not 1989:2005 [dp]").

It can be accepted that the correction and continuity procedure suggested by this dissimilitude follow the trace of the postdoctoral collaborator Martín-Zanca (Scherer, 2000).

\subsection{On an Experimental Basis}

One of the leaders (Barbacid) shall maintain that the Trk oncogene is the nerve growth factor (NGF) receptor.

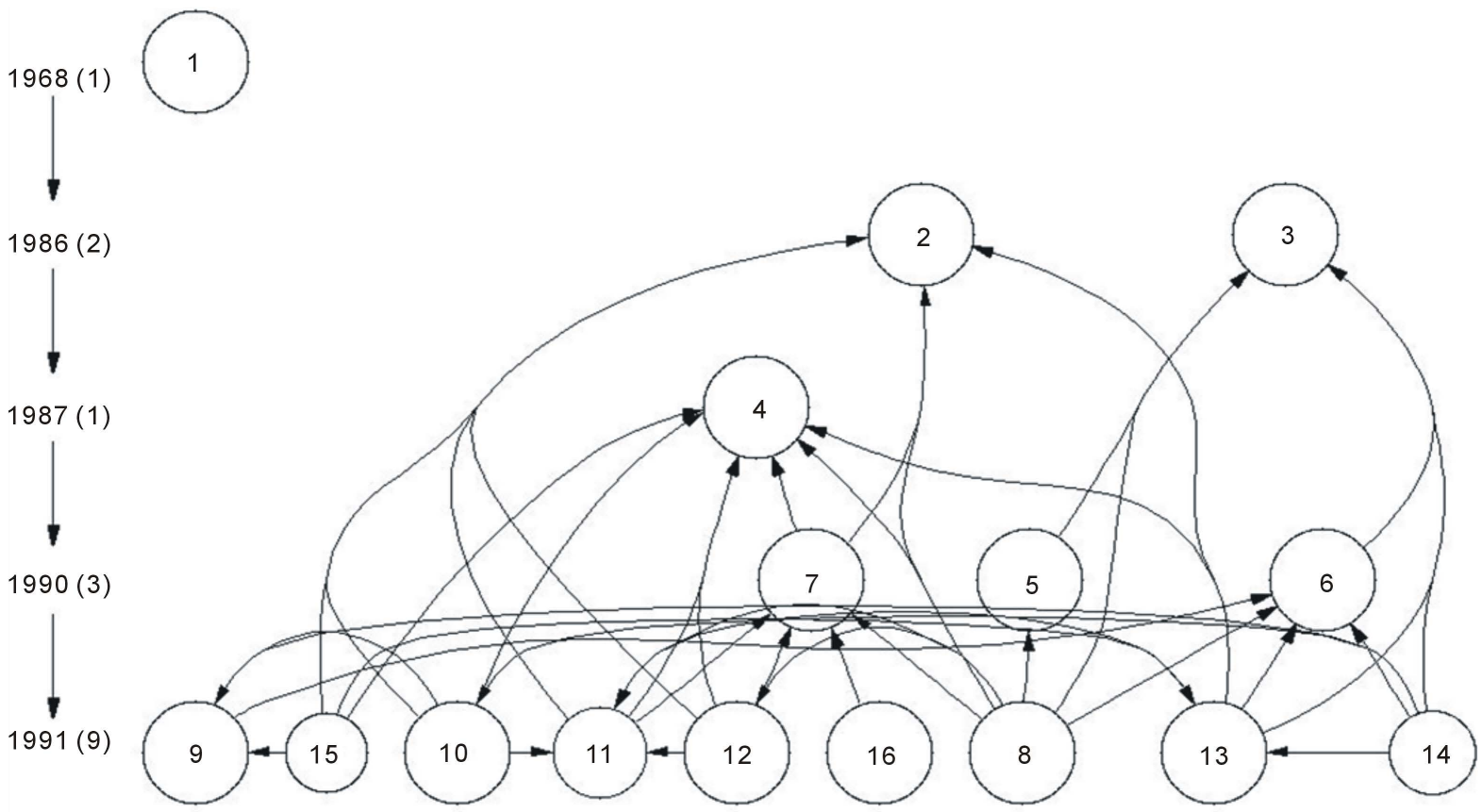

Figure 1. Coding for NGF receptors (Appendix 1).

Table 1. Mann-Whitney test for the scientific contents on Trk.

\begin{tabular}{cccc}
\hline $\begin{array}{c}\text { Question: TS = Trk and } \\
\text { AU }=\{\text { M-Z, Barbacid, Parada }\}\end{array}$ & U Statistic & $\begin{array}{c}\text { Acceptance } \\
\text { region }\end{array}$ & $\begin{array}{c}\text { Statistically significant difference } \\
\text { between research contents }\end{array}$ \\
\hline M-Z vs. Barbacid & 24 & $(21,+\infty)$ & Contents does not differ \\
M-Z vs. Parada & 53 & $(53,+\infty)$ & Contents does not differ \\
Parada vs. Barbacid & 36 & $(39,+\infty)$ & Significantly detectable difference \\
\hline
\end{tabular}


Supporting this hypothesis from his discovery of the oncogene in 1985 until today. The other leader (Parada) introduces an auxiliary assumption, to involve $p 75$ protein, before formulating a different hypothesis. That in 1991 will define the second "hottest" field in biology, promulgated by the ISI. Interestingly enough, a conspiracy was suggested behind the question on Trk working alone (Cherfas, 1994).

\subsection{On a Historical Basis (Cleland, 2001)}

This multiple hypothesis formulation, in competence, to explain a fact that has happened, the oncogene Trk discovery in colon cancer cells provide an opportunity to approach causal explanation in algorithmic historiography. A historiometric examination of this case makes available the right taxonomy of leadership (Garfield, Pudovkin, \& Istomin, 2003).

These causal etiologies, concerning the universe of publications and its influence, have their temporary threshold in April 1991 (on April 5 in the journal Cell in the case of Barbacid and on April 26 in the journal Science in the case of Martin-Zanca). Afterwards both Spaniards returned to Europe. One to conduct the newly formed CNIO (Spanish National Cancer Research Centre), and one to integrate a CSIC (Spanish National Research Council) institute located in Salamanca, west of Madrid.

From the graphical point of view, the convergence between Chao and Parada (in 1991) was the cover of Science ( $\mathrm{N}^{\circ}$ 5005, April 26, 1991). A specific university-level finding for the scientist whose training was supported by the Spaniards biochemists in the US (Levin \& Stephan, 1999), for which he had acted as a postdoc; and whose relatively short career close to Barbacid seems the result of an uncritical adoption of the results of a model overemphasized by social factors. An outcome that remind the situation of Dr Stehelin (also first author in a contribution communicating a crucial discovery) in a program awarded with the Nobel Prize in Medicine in 1989 (given to Varmus and Bishop) (Wulff Barreiro, 1996).

It is an undeniable challenge given that nowadays the $\mathrm{p} 75$ receptor functions continue to be intriguing (Barker, 2004). In this receptor are present the difficulties inherent in the "frontier objects", as in the painstaking process that follows the acknowledgment of the Spanish results relative to retinal apoptosis. In the central retina, dying cells create space for the axons converging to form the optic nerve. And this reconstruction of the retinal section moved towards increasing evidence on the signals generated by p75, as a promoter of programmed cell death (Cuadros, Coltey, Nieto, \& Martin, 1992) (Frade, Rodríguez-Tebar, \& Barde, 1996).

\section{Methodology}

To some extent the 1986 winner of the Nobel Prize for Medicine, Rita Levi-Montalcini, the director of the department of Physiology at New York University School of Medicine, Rodolfo R. Llinás, the emeritus professor of Genetics at Stanford University, Luigi L. Cavalli-Sforza, and the professor of Medical Genetics at Johns Hopkins University, Victor A. McKusick, have been engaged in this research program by communicating contributions from other authors to the US National Academy of Sciences. First, the "absence of consensus" is scrutinized through the analysis of the content of the contributions communicated by these four scientists.

The prosopographical analysis of the authors (López Piñero \& Terrada, 1993) (Shapin \& Thackray, 1974) invites to place the object of study between the problems faced within the OMIM (Online Mendelian Inheritance in Man) database, an institution that is a reference source in the subject. Entry \#164970 "Oncogene trk" (created on June 1986 by Victor A. McKusick, in 2006 it moved to \#191315, \#191030) facilitated the documents with which was elaborated a database ("p75, Trk") by using the software Procite ${ }^{\mathrm{TM}}$. This database covers a period of 23 years (1968-1991).

We searched all the documents included in the lists of references of the selected papers. And they were included in the database "p75, Trk" The basic information on these publications was obtained in Medline, the US.

National Library of Medicine bibliographic database. The objective pursued was to define the system of keywords used to describe its content; to do so it was used the field \#45 Keywords provided by the software "Procite".

The database also met the analysis of the review articles on the protein tyrosine kinases before the discovery of Trk oncogene (in 1985) and on the neurotrophin receptors, after it became apparent the absence of agreement between the authors (1993).

Special problems were confronted in managing the term "p75". Because it was not used as a descriptor by the database Medline (at least until 2005), all the searches were made against SCI. The analysis of the time series 
which has resulted from the use of the keyword "p75" in SCI, justified separate treatment in parallel to the developed through the database working with ProCite ${ }^{\mathrm{TM}}$.

The time interval 1968-91 was chosen to verify the development of the scientific interest in this topic. From the 1968 review contribution on NGF by Nobel awarded Levi-Montalcini, to 1991 Barbacid contribution on NGF receptor). The information flow analysis method was chosen as the most convenient for the quantification of this archive (Brozek \& Karen, 1979). Once exposed the system of descriptors, its temporal evolution was computed on an exponential basis, seeking to use also the Gompertz approach applied as an "exponential growth process limited by exponential retardation" (eg a sigmoidal function) (Akanuma, 1978). To analyze the data used to depict historical trends covering these years, we attempted to fit the Gompertz function. Because it adjust S-shaped better, and in its literature the growth of science is said to follow such a model. (Results are shown in Appendix 2 (Table A1 and Figure A1)).

In the introductory section software HistCite ${ }^{\mathrm{TM}}$ was employed to draft Figure 1.

\section{Results}

1121 keywords classify all the aspects used by the information flows in a database of 371 records, elaborated using the software ProCite ${ }^{\mathrm{TM}}$. Five of these descriptors are able to select 80 per cent of the contents in the database.

These descriptors are:

G-Growth factor

$\mathrm{N}-$ Nerve growth factor

$\mathrm{O}$-Oncogene

$\mathrm{R}$-Receptors cell surface

T-Tyrosine

We carry out the production of the indexes G/S, N/S, O/S, R/S, T/S, where $S$ is the sum of 80 percent of the total documents retrievable through this system of descriptors (G, N, O, R, T). Displayed over time these indexes can provide insights related to the historical development of the topic and the structure of its dynamic. (see Table 2).

In turn, the keyword "p75" in the database SCI selects 100 references. That can be spread over 17 thematic categories, as shown in the Table 3.

We are going to contrast the tendencies for interests in science that are displayed graphically in these two tables with the analysis of the empirical difficulties and the hypothesis formulated in the six contributions communicated by the four eminent scientists to the National Academy of Sciences of the US.

Table 2. The percentage of studies on neurotrophins, its receptors and oncogenes in the database “p75, Trk” (ProCiteTM)(\%).

\begin{tabular}{|c|c|c|c|c|c|}
\hline Year & 100. G/S & 100. N/S & 100. O/S & 100. R/S & 100. T/S \\
\hline 1968 & 0.33 & 0.33 & & & \\
\hline 1976 & 0.67 & 0.67 & & & \\
\hline 1977 & 1.35 & 1.35 & & & 0.33 \\
\hline 1979 & 0.33 & 0.33 & & & \\
\hline 1980 & 2.37 & 1.35 & 0.33 & 1.35 & \\
\hline 1981 & 1.35 & 1.01 & & 0.33 & \\
\hline 1982 & 1.69 & 1.69 & 0.67 & 0.67 & \\
\hline 1983 & 1.35 & 1.01 & 2.71 & 1.01 & 0.67 \\
\hline 1984 & 1.69 & 1.01 & 5.42 & 1.69 & 0.33 \\
\hline 1985 & 5.76 & 4.74 & 7.11 & 2.71 & 1.35 \\
\hline 1986 & 5.42 & 5.08 & 3.05 & 5.08 & 1.35 \\
\hline 1987 & 4.06 & 4.06 & 2.37 & 2.71 & 0.33 \\
\hline 1988 & 2.37 & 1.69 & 2.37 & 1.35 & 2.03 \\
\hline 1989 & 7.79 & 6.1 & 5.08 & 5.42 & 4.06 \\
\hline 1990 & 14.23 & 12.2 & 3.72 & 10.5 & 7.79 \\
\hline 1991 & 12.88 & 11.86 & 9.49 & 8.47 & 10.84 \\
\hline
\end{tabular}


Table 3. Distribution per thematic category in a search for papers using the term "p75”, during the period 1968-1991 (in the database SCI).

\begin{tabular}{ccc}
\hline Thematic category & $\mathrm{N}^{\circ}$ of records & $\%$ \\
\hline Immunology & 45 & 43.3 \\
Molecular biology and biochemistry & 13 & 12.5 \\
Hematology & 12 & 11.5 \\
Cell biology & 11 & 10.6 \\
Oncology & 11 & 10.6 \\
Experimental and research medicine & 9 & 8.7 \\
Multidisciplinary sciences & 5 & 4.8 \\
Biology & 4 & 3.8 \\
Genetics and Heredity & 4 & 3.8 \\
Surgery & 4 & 3.8 \\
Transplantations & 4 & 3.8 \\
Neuroscience & 3 & 2.9 \\
Pathology & 3 & 2.9 \\
Virology & 3 & 2.9 \\
Biochemical research methods & 2 & 1.9 \\
Gastroenterology and hepatology & 2 & 1.9 \\
Pediatrics & 2 & 1.9 \\
\hline
\end{tabular}

\subsection{For Levi-Montalcini}

Communicated on August 9, 1993. The debate is: whether Trk constitutes the high-affinity NGF receptor by itself or whether the functional receptor represents a complex of the low affinity NGF receptor and Trk (Ehrhard, Erb, Graumann, \& Otten, 1993).

Communicated on July 3, 1997. Reporting the discovery of small vesicles containing until one-third of the total Trk, and supporting the hypothesis that Trk receptors transduce the NGF signal from the platform of a small vesicle; in its turn it maintains that p75 does not appear to be down-regulated from the cell surface in response to NGF (Grimes, Beattie, \& Mobley, 1993).

\subsection{For Luigi L. Cavalli-Sforza}

Communicated on April 1, 1991 (and received for review February 21, 1991). The hypothesis is that the high-affinity NGF-receptor complex is a substrate of tyrosine kinase activity (Meakin \& Shooter, 1991).

\subsection{For Victor A. McKusick}

Communicated on January 9, 1995. Trk contains intrinsic tyrosine kinase activity, that has been located to the cytoplasmic domain, and it is thought that activation of this kinase represents the initial step in the intracellular signal transduction pathway of NGF. In brain cells a specific association of Trk with p75 was not observed (Mutoh, Tokuda, Miyadai, Hamaguchi, \& Fujiki, 1995).

\subsection{For Rodólfo R. Llinás}

Communicated on September 29, 1997. TrkC is the most likely transducer of neurotrophin-3 in heart development; and p75 lacks intrinsic enzymatic activity (Tessarollo, Tsoulfas, Donovan, Palko, Blair-Flynn, Hempstead, 1995).

The Trk proto-oncogenic form discovered by Barbacid in 1985, is identified as the NGF receptor codification, the hallmark of NGF receptors.

As for the cell surface protein, designated as p75, the message remains obscure. Looking at Figure 1 (see Appendix 1), we find in 1986 Article 2 the initial expression, in rats, of the gene encoding for the low affinity NGF receptor in human cells. It is Dr Chao program, of which Article 15 is a part, a study with a chimeric form 
of p75. Furthermore in Dr. Barde contribution, Article 7, biophysical properties are expressed, and p75 physiological relevance remains unclear.

On the other hand, Article 11 provides crucial results with the "brand" of the cell surface receptors inside the family of the tyrosine kinase proteins for the high affinity NGF receptors. Together articles 11 and 12 advanced that the high affinity NGF receptors contained an assemblage subunit different from p75.

As the title of this contribution shows, emphasis given to the idea of multiple discoveries, the interpersonal relations of the scientists, their milieu (Merton, 1963), are better understood by taking account the success of the "guiding assumption". The initial discovery of Trk proto-oncogen. The scope of empirical difficulties suggested by the auxiliar assumption (p75) actuate stimulating the capacity to solve problems of the main program (Trk), with no resolution through the auxiliar (p75) (Laudan, Laudan, \& Donovan, 1988).

\section{Conclusions}

Since its discovery in the 1950s nerve growth factor, a Rosetta Stone for understanding the biology of cancerogenesis, becomes one of the best-characterized members of a later identified family of neurotrophic factors. The experiments that led to it revealed its essential role in the embryonic development of the brain, and that it is also involved each time in new connections between nerve cells are established (e.g. at the time of learning). As NGF crystal structure provides a model for rational design of its derived drugs. Testing the NGF-receptor recognition was critical for a potential use of NGF and its relatives in the treatment of neurological disorders such as Alzheimer's disease and Parkinson's disease.

Mariano Barbacid, a molecular biologist at the Frederick Cancer Research Facility in Maryland, discovered the receptor for nerve growth factor (NGF) as a tyrosine kinase oncogene (in 1986), which he previously had identified in a human colon carcinoma biopsy (in 1982). But as a basic researcher he discarded its clinical applicability. In contrast, another Spanish biologist (Dionisio Martín-Zanca) at work inside his team, was involved with a Colombian (Luis Parada) from a lab that was also in the race to identify the lesion in the ras gene. A tale of two receptors resulted, that meant the renaissance of p75 as a signalling receptor with cell killing activities (Barbacid, 1993).

As every molecule tells a story, it must be noted that a "killer" (p75), better described as medicinal or pharmaceutical, came out really fast when receptor tyrosine kinases (Trk receptors) were isolated. It has been found that an original team characterizing the Trk gene splitted in two. Significant time has been expended to identify neurotrophins and their receptors. And Nobel award could have been granted to NGF receptor discovery. In any event, it is assumed that neurotrophins and their Trk receptors play a crucial role in the development and maintenance of the vertebrate nervous system. It needs to further sharpen the debate on "frontier objects" (like p75) that can be directed purposely to look for a cure.

The assertion formulated in the summary concerning the general consensus on the p75/Trk heterodimer model, as depicted in Figure 1 by articles Nr. 9, 15, 10, 13 and 14, is contradicted by the lack of biochemical evidence (immunoprecipitation studies) concerning the mechanism by which the p75 neurotrophin receptor and TrkA interact (as maintained in the Articles 6, 5, 8, 12 and 11).

p75 was regarded as a "drifting biological object" during the decade 1994-2004. Only the potential therapeutic utility of neurotrophins as an agent for clinical use, seems to have relaunched until now incomplete understanding of the complexe molecular mechanisms with which this protein (p75) exerts their actions (He \& Farcia, 2004).

From the classical embryological observations of Viktor Hamburger, through the identification and purification of NGF by Levi-Montalcini, Barbacid provided the first molecular verification of tyrosine kinase protooncogene as the NGF receptor.

\section{Acknowledgements}

Dr. Andrés Jiménez (University of Cádiz), Dr. John Pezzullo (Georgetown University).

\section{References}

Akanuma, A. (1978). Parameter Analysis of Gompertzian Function Growth Model in Clinical Tumors. European Journal of Cancer, 14, 681-688. http://dx.doi.org/10.1016/0014-2964(78)90304-3 
Barbacid, M. (1993). Nerve Growth Factor: A Tale of Two Receptors. Oncogene, 8, 2033-2042.

Barker, P. A. (2004). P75NTR Is Positively Promiscuous: Novel Partners and New Insights. Neuron, 42, 529-533. http://dx.doi.org/10.1016/j.neuron.2004.04.001

Brozek, V., \& Karen, P. (1979). Dynamics of Information Flow in the Field of Rare Earth Carbides Research. Scientometrics, 1, 339-357. http://dx.doi.org/10.1007/BF02019305

Cherfas, J. (1994). Does Trk Protein Act Alone, Or Is It a Conspiracy? Current Contents, 22, 3-5.

Cleland, C. E. (2001). Historical Science, Experimental Science, and the Scientific Method. Geology, 29, 987-990. http://dx.doi.org/10.1130/0091-7613(2001)029<0987:HSESAT>2.0.CO;2

Conover, W. J. (1980). Practical Nonparametric Statistics (2nd ed.). New York: Wiley.

Cuadros, M. A., Coltey, P., Nieto, Ma. C., \& Martin, C. (1992). Demonstration of Phagocytic Cell System Belonging to the Hemopoietic Lineage and Originating from the Yolk sac in the Early Avian Embryo. Development, 115, 157-168.

Egghe, L., \& Rousseau, R. (1990). Introduction to Informetrics. Amsterdam: Elsevier.

Ehrhard, P. B., Erb, P., Graumann, U., \& Otten, U. (1993). Expression of Nerve Growth Factor and Nerve Growth Factor Receptor Tyrosine Kinase Trk in Activated CD4-Positive T-Cell Clones. Proceedings of National Academy of Sciences USA, 90, 10984-10988. http://dx.doi.org/10.1073/pnas.90.23.10984

Frade, J. Ma., Rodríguez-Tebar, A., \& Barde, Y.-A. (1996). Induction of Cell Death by Endogenous Nerve Growth Factor through Its p75 Receptor. Nature, 383, 166-168. http://dx.doi.org/10.1038/383166a0

Garfield, E., Pudovkin, A. I., \& Istomin, V. S. (2003). Why Do We Need Algorithmic Historiography? Journal of the American Society for Information Science and Technology (JASIST), 54, 400-412. http://dx.doi.org/10.1002/asi.10226

Grimes, M. L., Beattie, E., \& Mobley, W. C. (1997). A Signaling Organelle Containing the Nerve Growth Factor-Activated Receptor Tyrosine Kinase, TrkA. Proceedings of National Academy of Sciences USA, 94, 9909-9914. http://dx.doi.org/10.1073/pnas.94.18.9909

He, X.-L., \& Farcía, C. (2004). Structure of Nerve Growth Factor Complexed with the Shared Neurotrophin Receptor p75. Science, 304, 870-875. http://dx.doi.org/10.1126/science.1095190

Krimsky, S. (2002). Who Owns Academic Work? Battling for Control of Intellectual Property. By Corynne McSherry. Harvard University Press, 2001. Nature Medicine, 8, 325. http://dx.doi.org/10.1038/nm0402-325

Laudan, R., Laudan, L., \& Donovan, A. (1988). Testing Theories of Scientific Change. In A. Donovan, L. Laudan, \& R. Laudan (Eds.), Scrutinizing Science: Empirical Studies of Scientific Change (pp. 3-44). Dordrecht [etc.]: Kluwer. http://dx.doi.org/10.1007/978-94-009-2855-8_1

Levin, S. G., \& Stephan, P. E. (1999). Sociology of Science-Are the Foreign Born a Source of Strength for U.S. Science? Science, 285, 1213-1214. http://dx.doi.org/10.1126/science.285.5431.1213

López Piñero, J. M. ${ }^{a}$, \& Terrada, M ${ }^{\mathrm{a}}$ L. (1993). Veinte años de investigación bibliométrica en el Instituto de Estudios Documentales e Históricos sobre la Ciencia. Valencia: Universidad, CSIC.

Meakin, S. O., \& Shooter, E. M. (1991). Tyrosine Kinase Activity Coupled to the High-Affinity Nerve Growth Factor-Receptor Complex. Proceedings of National Academy of Sciences USA, 88, 5862-5866.

http://dx.doi.org/10.1073/pnas.88.13.5862

Merton, R. K. (1963). Resistance to the Systematic Study of Multiple Discoveries in Science. European Journal of Sociology, 4, 237-249. http://dx.doi.org/10.1017/S0003975600000801

Mutoh, T., Tokuda, A., Miyadai, T., Hamaguchi, M., \& Fujiki, N. (1995). Ganglioside GM1 Binds to the Trk Protein and Regulates Receptor Function. Proceedings of National Academy of Sciences USA, 92, 5087-5091.

http://dx.doi.org/10.1073/pnas.92.11.5087

Pellicer, A. (2004). Contribución de los científicos españoles en Estados Unidos a la bioquímica. In E. Muñoz (Ed.), Cuarenta años de la Sociedad Española de Bioquímica y Biología Molecular (1963-2003) (pp. 227-248). Madrid: SECC.

Scherer, F. M. (2000). The Emigration of German-Speaking Economists after 1933. Journal of Economic Literature, XXXVIII, 614-626. http://dx.doi.org/10.1257/jel.38.3.614

Shapin, S., \& Thackray, A. (1974). Prosopography as a Research Tool in History of Science: The British Scientific Community 1700-1900. History of Science, 12, 1-28. http://dx.doi.org/10.1017/S000708740001284X

Siegel, G. J. (1999). Basic Neurochemistry: Molecular, Cellular and Medical Aspects (6th ed.). Philadelphia, Lippincott: Williams \& Wilkins.

Tessarollo, L., Tsoulfas, P., Donovan, M. J., Palko, M. E., Blair-Flynn, J., Hempstead, B. L., \& Parada, L. F. (1997). Targeted Deletion of All Isoforms of the trkC Gene Suggests the Use of Alternate Receptors by Its Ligand Neurotrophin-3 in Neuronal Development and Implicates trkC in Normal Cardiogenesis. Proceedings of National Academy of Sciences USA, 94, 14776-14781. http://dx.doi.org/10.1073/pnas.94.26.14776 
Vecino, E. (1998). Las neurotrofinas y su uso en la clínica. Archivos de la Sociedad Española de Oftalmología, 11.

Wulff Barreiro, E. (1996). History of the Discovery of the Origins of the Tumor Formation: Dr. Barbacid's Program at the Beginning of the Research on Oncogenes. Llull, 19, 525-550. 


\section{Appendix 1}

List of articles used in Figure 1: Coding for NGF Receptors. With Global Citation Score (GCS) [Access to the SCI database in July 5, 2005].

1) Levi Montalcini, R. \& Angeletti, P. U. (1968). Nerve Growth Factor. Physiological Reviews, 48, 534-569. GCS: 1668.

2) Johnson, D., Lanahan, A., Buck, C. R., Sehgal, A., Morgan, C., Mercer, E., Bothwell, M., \& Chao, M. (1986). Expression and Structure of the Human NGF Receptor. Cell, 47, 545-554. GCS: 750.

3) Martin Zanca, D., Hughes, S. H., \& Barbacid, M. (1986). A Human Oncogene Formed by the Fusion of Truncated Tropomyosin and Protein Tyrosine Kinase Sequences. Nature, 319, 743-748. GCS: 488.

4) Radeke, M. J., Misko, T. P., Hsu, C., Herzenberg, L. A., \& Shooter, E. M. (1987). Gene-Transfer and Molecular-Cloning of the Rat Nerve Growth-Factor Receptor. Nature, 325, 593-597. GCS: 763.

5) Klein, R., Conway, D., Parada, L. F., \& Barbacid, M. (1990). The trkB Tyrosine Protein-Kinase Gene Codes for a $2^{\text {nd }}$ Neurogenic Receptor That Lacks the Catalytic Kinase Domain. Cell, 61, 647-656. GCS: 482.

6) Martin Zanca, D., Barbacid, M., \& Parada, L. F. (1990). Expression of the trk Protooncogene Is Restricted to the Sensory Cranial and Spinal Ganglia of Neural Crest Origin in Mouse Development. Genes \& Development, 4, 683-694. GCS: 296.

7) Rodríguez Tebar, A., Dechant, G., \& Barde, Y. A. (1990). Binding of Brain-Derived of Brain-Derived Neurotrophic Factor to the Nerve Growth-Factor Receptor. Neuron, 4, 487-492. GCS: 517.

8) Klein, R., Jing, S.Q., Nanduri, V., O’Rourke, E., \& Barbacid, M. (1991). The trk Protooncogene Encodes a Receptor for Nerve Growth-Factor. Cell, 65, 189-197. GCS: 1074.

9) Kaplan, D. R., Martín Zanca, D., \& Parada, L. F. (1991). Tyrosine Phosphorylation and Tyrosine KinaseActivity of the trk Protooncogene Product Induced by NGF. Nature, 350, 158-160. GCS: 739.

10) Hempstead, B. L., Martín Zanca, D., Kaplan, D. R., Parada, L. F., \& Chao, M. V. (1991). High-Affinity NGF Binding Requires Coexpression of the trk Protooncogene and the Low-Affinity NGF Receptor. Nature, 350, 678-683. GCS: 899.

11) Meakin, S. O., \& Shooter, E. M. (1991). Molecular Investigations on the High-Affinity Nerve GrowthFactor Receptor. Neuron, 6, 153-163. GCS: 129.

12) Weskamp, G., \& Reichardt, L. F. (1991, April). Molecular Investigations on the High-Affinity Nerve Growth-Factor Receptor. Neuron, 6, 153-163. GCS: 221.

13) Kaplan, D. R., Hempstead, B. L., Martín Zanca, D., Chao, M. V., \& Parada, L. F. (1991, 26 April). The trk Protooncogene Product-A Signal Transducing Receptor for Nerve Growth-Factor. Science, 252, 554-558. GCS: 1011.

14) Nebreda, A. R., Martín Zanca, D., Kaplan, D. R., Parada, L. F., \& Santos, E. (1991, April 26). Induction by NGF of Meiotic Maturation of Xenopus Oocytes Expressing the trk Protooncogene Product. Science, 252, 558-560. GCS: 104.

15) Yan, H., Schlessinger, J., \& Chao, M. V. (1991, April 26). Chimeric NGF-EGF Receptors Define Domains Responsible for Neuronal Differentiation. Science, 252, 561-563. GCS: 100.

16) Thoenen, H. (1991 May). The Changing Scene of Neurotrophic Factors. Trends in Neurosciences, 14, 165-170. GCS: 698. 


\section{Appendix 2}

Table A1. Prognosis for the development of the information flows for the years 1992, 1993, 1994 and 2004.

\begin{tabular}{|c|c|c|c|c|c|}
\hline Information flow & $\mathrm{Y}_{1992}$ & $Y_{1993}$ & $Y_{1994}$ & $Y_{2004}$ & Note \\
\hline \multirow[t]{2}{*}{ G } & 12.78 & 15.77 & 19.46 & 158.9 & EXP \\
\hline & 16.97 & 21.19 & 26.35 & 187.54 & GOM \\
\hline \multirow[t]{2}{*}{$\mathrm{N}$} & 10.78 & 13.17 & 16.09 & 118.9 & EXP \\
\hline & 15.37 & 19.47 & 24.56 & 197.57 & GOM \\
\hline $\mathrm{O}$ & 8.68 & 10.61 & 12.96 & 95.78 & EXP \\
\hline (without Gompertz & & & & & GOM \\
\hline adjustment) & 10.05 & 12.78 & 16.25 & 179.11 & EXP \\
\hline \multirow[t]{2}{*}{$\mathrm{R}$} & 11.91 & 14.92 & 18.59 & 129.2 & GOM \\
\hline & 5.9 & 7.74 & 10.14 & 150.89 & EXP \\
\hline \multirow[t]{2}{*}{$\mathrm{T}$} & 17.68 & 27.54 & 42.18 & 1345.06 & GOM \\
\hline & 67.25 & 153.34 & 218.02 & 433.68 & EXP \\
\hline p75 & 112.55 & 185.45 & 261.67 & 496.08 & GOM \\
\hline
\end{tabular}

$\mathrm{Y}_{1992}, \mathrm{Y}_{1993}, \mathrm{Y}_{1994}, \mathrm{Y}_{2004}$ the predicted volumes of information for the years 1992, 1993, 1994 and 2004 expressed as a percentage figure. The appointments EXP or GOMP express the method to extrapolate, either the exponential function, or the Gompertz distribution. The descriptors are: GGrowth factor; $\mathrm{N}$-Nerve growth factor; $\mathrm{O}$-Oncogene; $\mathrm{R}$-Cell surface receptors; $\mathrm{T}$ - Tyrosine; p75—p75 protein.

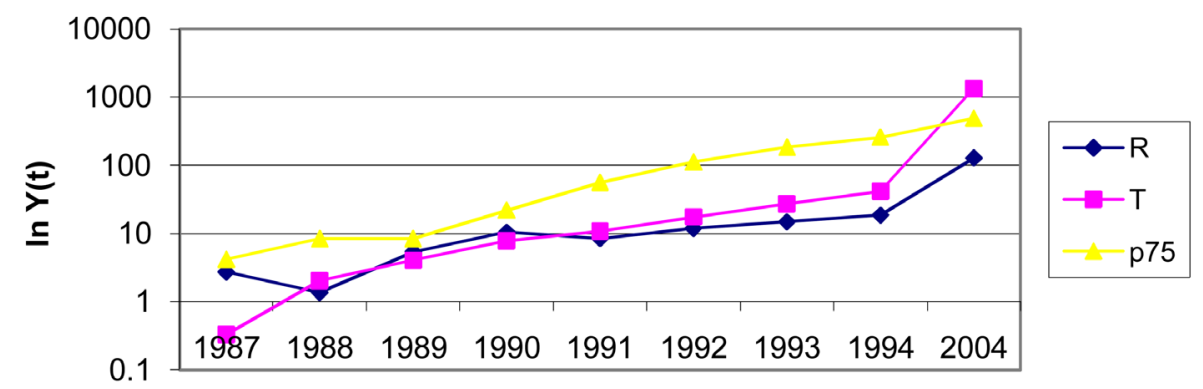

Figure A1. Development of the information flows: R (Cell surface receptors), T (Tyrosine kinase), p75. Gompertz Function. (Curve Expert 1.3 $\left.{ }^{\odot}\right)$; R: $Y(t)=212533.39 \times$ Exp (-Exp $(2.58-0.023 \times \mathrm{t})) ; \mathrm{T}: \mathrm{Y}(\mathrm{t})=1948248.1 \times \operatorname{Exp}(-\operatorname{Exp}(2.84-0.03 \times \mathrm{t})) ; \mathrm{P} 75: \mathrm{Y}(\mathrm{t})=$ $5038558.1 \times \operatorname{Exp}(-\operatorname{Exp}(2.67-0.022 \times \mathrm{t}))$. 